\title{
Interrelationships of Five Species of the Genus Labeo by Morphometric Analysis
}

\author{
${ }^{1}$ S. Choudhury, ${ }^{2}$ Dr. K. Dutta \\ '(CSIR-JRF, Department of Zoology, Gauhati University, Guwahati-14, Assam, India.) \\ ${ }^{2}$ (PROFESSOR, Department of Zoology, Gauhati University, Guwahati-14, Assam, India.)
}

\begin{abstract}
The genus Labeo under Cyprinidae family is of much importance as many species under this genus are ornamental species, some food species, some used for extracting oil, some considered to be of medicinal value etc. Morphometric studies were conducted using eleven quantitative body parameters of five species of Labeo genus - Labeo bata, L .calbasu, L . rohita, L . pangusia and L . dyocheilus occurring from Assam, India, in order to identify the morphometric variation and taxonomic relationship among these species. All measurements were taken on a continuous scale using digital vernier caliper parallel to the anterior-posterior body axis except for the body depth that was taken perpendicular to the body axis between dorsal and ventral margins. The means of all measurements were standardized and multivariate cluster and principal component analysis were conducted using bdpro32 software. A dendrogram has been prepared showing the relatedness among the species. The results obtained on the basis of morphometric variation among the species using cluster analysis showed that $L$. bata is most distantly related whereas $L$. rohita and $L$. calbasu are most closely related with a similarity of 98.3965 (distance $=1.6035$ ) followed by $L$. pangusia and $L$. dyocheilus. The scores of PC1, PC2 and PC3 are also most similar between L. rohita and L. calbasu. The findings of this study will help in developing new strategies for conservation and breeding programmes of these species.
\end{abstract}

Keywords: Cluster analysis, dendrogram, Labeo genus, morphometric variation, principal component analysis, taxonomic relationship.

\section{Introduction:}

The state of Assam, India, which lies in two biodiversity hotspot regions of the world (The Himalayas and the Indo-Burma), harbours a large variety of threatened and endemic flora and fauna including a large variety of fishes. Since fishes are the most ancient group of the vertebrates, their diversity and taxonomic studies is very necessary. Cyprinids are the major component of Indian freshwater fish fauna with respect to the number both of individuals and of species. The role of this family within freshwater ecosystem is therefore central. The genus Labeo under Cyprinidae family is of much importance as many species under this genus are ornamental species, some food species, some are used for extracting oil and some are considered to be of medicinal value etc. Morphometric characters have been commonly used in fisheries biology as powerful tools for measuring discreteness and relationships among various taxonomic categories [1].

Understanding the origins, maintenance and consequences of variation is a fundamental part of biological research and requires that variation be both precisely and accurately estimated. Complex variation associated with body form is one of the most difficult types of variation to quantify and the methods used to access it are collectively referred to as morphometrics [2].These methods are concerned with quantifying shape variation within and among samples usually to address developmental and evolutionary questions relating to shape change during growth. Morphometrics is a field concerned with studying variation and change in the form (size and shape) of organisms or objects [3]. There are several methods for extracting data from shapes, each with their own benefits and weaknesses. These include measurement of lengths and angles, landmark analysis and outline analysis. Morphometrics adds a quantitative element to descriptions, allowing more rigorous comparisons. It enables one to describe complex shapes in a rigorous fashion, and permits numerical comparison between different forms [4] and when combined with multivariate statistical methods (e.g. Principal Component Analysis, Cluster Analysis etc) they offer powerful tool for testing and displaying differences in shape [5] [6]. All landmark based morphometric methods face the fundamental challenge of removing variation in size from variation in shape. Traditional morphometrics uses one of three general approaches to try to isolate shape from size variation: ratios, regression and multivariate factor or component analysis [7] [8].

Application of morphometrics in Labeo genus for study of taxonomic relationship is limited and is still an open issue in this region. Thus, the present study had been undertaken with the main objective to analyze possible morphometric variations using various measurements of the body parts and identify the interrelationship among the selected species. 


\section{Materials \& Methods:}

A total of fifty specimens, ten for each of the five species of fish of Labeo genus under Cyprinidae family: Labeo bata, L .calbasu, L . rohita, L . pangusia and L. dyocheilus were collected from the water bodies of Assam by random sampling. The species were identified by the characters described by [9] [10]. No significant sexual dimorphisin with respect to the selected morphometrics was observed; therefore the data analyses were performed without taking the sex of the individual into consideration.

Eleven measurements were taken from the lateral side of the fish on a continuous scale using digital vernier caliper. All lengths were taken parallel to the anterior-posterior body axis except for the body depth that was taken perpendicular to the body axis between dorsal and ventral margins [11].The mean of the data for each species were calculated and also the standard deviation. The mean values have been used for the analysis (Table Besides effects from the environment and evolutionary history, morphometric characters may contain growth and/or allometric trends. To correct for (relative) differences in size all measurements have been standardized (expressed as proportions of total length Vs other measurements (Fig: 1, Table 2). Moreover, selecting specimens from a specific size range may also contribute in the elimination of growth trends. Multivariate cluster analysis and principal component analysis were conducted using the standardized morphometric data with the help of bdpro32 software [12].

Table 1: Data of the measurements of the mean body parameters.

\begin{tabular}{|l|c|c|c|c|c|}
\hline \multicolumn{1}{|c|}{$\begin{array}{c}\text { Mean body } \\
\text { parameters (cm) }\end{array}$} & \multicolumn{5}{c|}{ Species } \\
\cline { 2 - 6 } & $\begin{array}{c}\text { Labeo } \\
\text { bata }\end{array}$ & $\begin{array}{c}\text { Labeo } \\
\text { calbasu }\end{array}$ & $\begin{array}{c}\text { Labeo } \\
\text { rohita }\end{array}$ & $\begin{array}{c}\text { Labeo } \\
\text { Langusia }\end{array}$ & $\begin{array}{c}\text { dyocheilu } \\
\text { sabeo }\end{array}$ \\
\hline Total length & 32.003 & 28.883 & 32.000 & 31.261 & 25.355 \\
\hline Standard length & 26.720 & 23.337 & 27.904 & 25.759 & 21.475 \\
\hline Fork length & 28.992 & 25.272 & 29.696 & 28.041 & 23.123 \\
\hline Pre-anal length & 19.968 & 17.763 & 22.304 & 18.850 & 17.520 \\
\hline Pre- dorsal length & 11.168 & 10.744 & 12.736 & 11.097 & 10.420 \\
\hline Pre-pelvic length & 13.184 & 12.968 & 14.336 & 12.754 & 12.119 \\
\hline Pre-pectoral length & 5.536 & 5.689 & 5.920 & 5.752 & 4.817 \\
\hline Body depth & 7.360 & 6.816 & 7.456 & 5.533 & 7.124 \\
\hline Head length & 5.728 & 5.632 & 6.304 & 6.314 & 5.172 \\
\hline Eye diameter & 1.747 & 1.188 & 1.280 & 1.161 & 0.848 \\
\hline Pre-orbital length & 1.145 & 1.582 & 1.708 & 2.052 & 2.363 \\
\hline
\end{tabular}

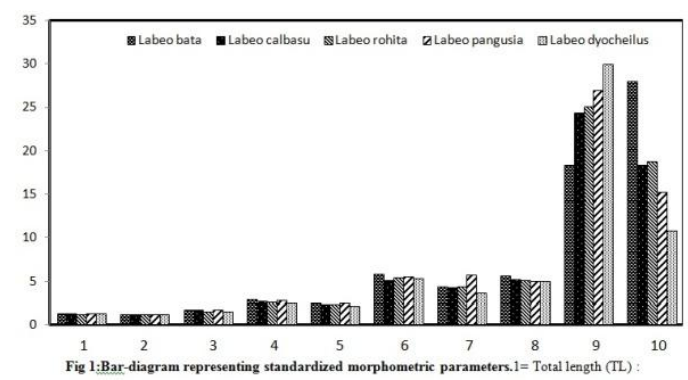

Fig 1:Bar-diagram representing standardized $\mathbf{m}$ orphometric parameters. $1=$ Total length $(\mathrm{TL}):$ Standard length (SL); 2 = TL : Fork Length; 3 = TL : Pre-anal Length; 4 = TL : Pre-dorsal Length; 5 = TL : Pre-pelvic Length; $6=$ TL : Pre-pectoral Length; 7 = TL : Body Depth; $8=$ TL : Head Length; $9=$ TL : Eye diameter; $10=$ TL : Pre-orbital Length.

Table 2: Data of the standardized body parameters.

\begin{tabular}{|l|l|l|l|l|l|}
\hline Standardized body parameters: & & & Species & & \\
\cline { 2 - 6 } & $\begin{array}{l}\text { Labeo } \\
\text { bata }\end{array}$ & $\begin{array}{l}\text { Labeo } \\
\text { calbasu }\end{array}$ & $\begin{array}{l}\text { Labeo } \\
\text { rohita }\end{array}$ & $\begin{array}{l}\text { Labeo } \\
\text { pangusia }\end{array}$ & $\begin{array}{l}\text { Labeo } \\
\text { dyocheilus }\end{array}$ \\
\hline $\begin{array}{l}\text { Total length (TL) : Standard length } \\
\text { (SL) }\end{array}$ & 1.197 & 1.237 & 1.146 & 1.213 & 1.180 \\
\hline TL : Fork Length & 1.103 & 1.142 & 1.077 & 1.114 & 1.096 \\
\hline TL : Pre-anal Length & 1.602 & 1.626 & 1.434 & 1.658 & 1.447 \\
\hline TL : Pre-dorsal Length & 2.865 & 2.688 & 2.512 & 2.817 & 2.433 \\
\hline TL : Pre-pelvic Length & 2.427 & 2.227 & 2.232 & 2.451 & 2.092 \\
\hline
\end{tabular}


Interrelationships Of Five Species Of The Genus Labeo By Morphometric Analysis

\begin{tabular}{|l|c|c|c|c|c|}
\hline TL : Pre-pectoral Length & 5.780 & 5.076 & 5.405 & 5.434 & 5.263 \\
\hline TL : Body Depth & 4.348 & 4.237 & 4.291 & 5.649 & 3.559 \\
\hline TL : Head Length & 5.587 & 5.128 & 5.076 & 4.951 & 4.902 \\
\hline TL : Eye diameter & 18.318 & 24.312 & 25.000 & 26.925 & 29.899 \\
\hline TL : Pre-orbital Length & 27.950 & 18.257 & 18.735 & 15.234 & 10.730 \\
\hline
\end{tabular}

III. Results And Discussion:

The results of the multivariate cluster analysis of the present study have been summarized in Table 3 . Similarity matrix values were calculated for all standardized morphometric parameters. The similarity was found to be highest between Labeo rohita and Labeo calbasu (98.3965), between L.rohita and L.pangusia the similarity was 94.2019, between L.calbasu and L.pangusia (93.9869), between L.pangusia and L.dyocheilus (91.7007), between L.rohita and l.dyocheilus (89.0069), between L.calbasu and L.dyocheilus (88.4254), between L.calbasu and L.bata (87.2793), between L.rohita and L.bata (87.2303), between L.bata and L.pangusia (82.8593). The least similarity was found between L.bata and L.dyocheilus (76.2756).

Table 3: Summary of the results of the multivariate cluster analysis based on the variation in the standardized morphometric parameters of the selected species.

\begin{tabular}{|l|c|c|c|c|c|}
\hline \multicolumn{1}{|c|}{ Step } & Clusters & Distance & Similarity & Joined 1 & Joined 2 \\
\hline \multicolumn{1}{|c|}{$\mathbf{2}$} & 4 & 1.603456616 & 98.39654338 & 2 & 3 \\
\hline $\mathbf{3}$ & 3 & 5.798114777 & 94.20188522 & 2 & 4 \\
\hline $\mathbf{4}$ & 2 & 8.299308777 & 91.70069122 & 2 & 5 \\
\hline $\begin{array}{l}\text { Similarity } \\
\text { Matrix }\end{array}$ & 1 & 12.7207222 & 87.2792778 & 1 & 2 \\
\hline & & & & \\
\hline Labeo bata & $\begin{array}{l}\text { Labeo } \\
\text { bata }\end{array}$ & $\begin{array}{l}\text { Labeo } \\
\text { calbasu }\end{array}$ & $\begin{array}{l}\text { Labeo } \\
\text { rohita }\end{array}$ & $\begin{array}{l}\text { Labeo } \\
\text { pangusia }\end{array}$ & $\begin{array}{l}\text { Labeo } \\
\text { dyocheilus }\end{array}$ \\
\hline Labeo calbasu & $*$ & $*$ & 87.2793 & 82.8593 & 76.2756 \\
\hline Labeo rohita & $*$ & $*$ & $*$ & 93.9869 & 88.4254 \\
\hline $\begin{array}{l}\text { Labeo } \\
\text { pangusia }\end{array}$ & $*$ & $*$ & $*$ & $*$ & 89.0069 \\
\hline $\begin{array}{l}\text { Labeo } \\
\text { dyocheilus }\end{array}$ & $*$ & $*$ & $*$ & $*$ & \\
\hline
\end{tabular}

A single-link bray-curtis cluster analysis dendrogram was constructed from the combined data for all standardized morphometric parameters showing the relationship among the selected species of Labeo (Fig: 2). The most closely related species were found to be Labeo rohita and L.calbasu followed by L.pangusia and L.dyocheilus while L.bata was found to be most distantly related.

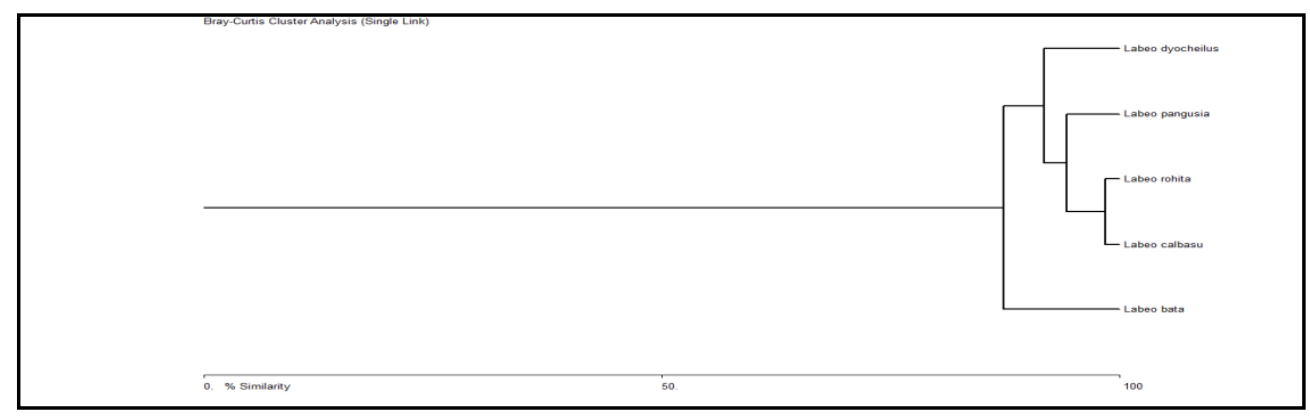

Fig 2: Bray-Curtis Cluster Analysis (Single Link) dendrogram

Details of the results of the principal component analysis have been listed in Table 4. Three principal components were extracted where the Eigen value of PC1 is 5.38779, PC2 $=2.98844$ and PC3 $=1.42567$. The scores of PC1, PC2 and PC3 of L. calbasu $(\mathrm{PC} 1=4.74959, \mathrm{PC} 2=0.23272$ and $\mathrm{PC} 3=-4.88328)$ and $L$. rohita $(\mathrm{PC} 1=4.58594, \mathrm{PC} 2=0.00993$ and $\mathrm{PC} 3=-5.11625)$ are most similar and the relative positions of these two species in a projection of the $1^{\text {st }}, 2^{\text {nd }}$ and $3^{\text {rd }}$ principal components in Fig:3 indicates that they tend to group together. The PC1, PC2 and PC3 scores of L. bata are the most different from the rest indicating this species to be most distantly related. 
Interrelationships Of Five Species Of The Genus Labeo By Morphometric Analysis

Table 4 : Summary of the results of the principal component analysis

\begin{tabular}{|l|r|r|c|}
\hline Proportions & & & \\
\hline Eigenvalue & 5.38779 & 2.98844 & 1.42567 \\
\hline Components & & & \\
\hline Variable & PC1 & PC2 & PC3 \\
\hline $\begin{array}{l}\text { Total length (TL) : Standard length } \\
\text { (SL) }\end{array}$ & 0.21065 & 0.46436 & 0.26246 \\
\hline TL : Fork Length & 0.16152 & 0.4778 & 0.35233 \\
\hline TL : Pre-anal Length & 0.34581 & 0.34323 & -0.0293 \\
\hline TL : Pre-dorsal Length & 0.42084 & 0.09686 & -0.09671 \\
\hline TL : Pre-pelvic Length & 0.38682 & 0.00385 & -0.36859 \\
\hline & & - & \\
TL : Pre-pectoral Length & 0.26421 & 0.39187 & -0.23699 \\
\hline TL : Body Depth & 0.24145 & 0.21411 & -0.60102 \\
\hline TL : Head Length & 0.32754 & -0.2926 & 0.33964 \\
\hline TL : Eye diameter & -0.35582 & 0.24994 & -0.27442 \\
\hline & & - & \\
TL : Pre-orbital Length & 0.34816 & 0.28529 & 0.22991 \\
\hline Scores & & & \\
\hline Variable & PC1 & PC2 & PC3 \\
\hline & & - & -1.20191 \\
\hline Labeo bata & 10.74909 & 4.44466 & -4.88328 \\
\hline Labeo calbasu & 4.74959 & 0.23272 & -5.11625 \\
\hline Labeo rohita & 4.58594 & 0.00993 & -7.4011 \\
\hline Labeo pangusia & 3.28729 & 1.96189 & -7.81209 \\
\hline Labeo dyocheilus & -0.28819 & 3.48909 & \\
\hline
\end{tabular}

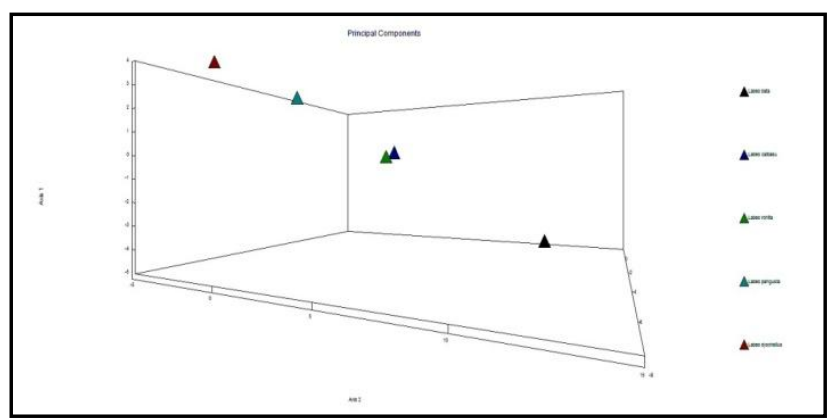

Fig 3: Result of Principal Component Analysis.

The species of Labeo genus are identified conventionally based on morphological and meristic characters, relying mainly on the meristic counts, pigmentation pattern and colouration of the skin. The morphological approach cannot be used to establish the similarity/dissimilarity among the species i.e. taxonomic relationship among the species. The morphological approach is beset with problems including wide variation in the colour pattern between mating and non mating seasons of the same individuals of the same species. Thus, supportive techniques like the one we have used in this study are needed to ratify the taxonomic status and relationship of these species which are very important from both fisheries and aquaculture points of views.

The results of the present investigation clearly showed the relationships among the species and have grouped them into clusters on the basis of their morphometric variations. Labeo rohita and L. calbasu which are morphologically different are grouped together in one cluster, inferring that these two species are most similar to each other and are the descendents of a very near common ancestor. The present study provides the pioneering report on the application of morphometric analysis of the selected species from this region. Morphometric studies have been widely used to discriminate the populations of various fish species [13] and have been able to identify differences between fish taxa [14]. [15] identified different variants in a fish species Etroplus maculatus by morphometric analysis. [16] identified the relationships among six species of Puntius on the basis of morphometric variation among them. 


\section{Conclusion}

The use of morphometry is an easy to implement method, relatively rapid and also inexpensive. Since the connectivity between species and their taxonomic relationship is a major point for conservation and management of species, the use of morphometry to this purpose appears to be very promising and the results of the present study may be a useful reference for further investigations and developing new strategies for conservation and breeding programmes of these species. A definite confirmation of the taxonomic relationships of these species has to wait till an extensive set of characters, such as DNA sequences, become available.

\section{Acknowledgement:}

The authors are grateful to CSIR, New Delhi, for providing the CSIR Junior Research Fellowship.

\section{References:}

[1] Quilang, J. P., Basiao, Z. U., Pagulayan, R. C., Roderos, R. R. and Barrios, E. B. Meristic and morphometric variation in the silver perch, Leiopotherapon plumbeus (Kner, 1864), from three lakes in the Philippines. Journal of Applied Ichthyology, 23, 2007, 561-567

[2] Parsons, K.J. Robinson, B.W. and Hrbek, T. Getting into shape: an empirical comparison of traditional truss-based morphometric methods with a newer geometric method applied to New World cichlids. Environ Biol Fishes, 67, 2003, 417-431.

[3] Rohlf, F.J. and Marcus, L.F. A revolution in morphometrics..Trends in Ecology and Evolution, 8, 1993, $129-132$.

[4] Bookstein, F. L. Morphometric tools for landmark data: geometry and biology (Cambridge, Cambridge Univ. Press, 1991).

[5] Loy, A., Corti, M. and Marcus, L.F. Landmark data: size and shape analysis in systematics. A case study on old world Talidae (Mammalia, Insectivora). In LFMarcus, E.Bellow, A.Garcia - Valdacases, (eds). Contributions to morphometrics, 1993, 213-240.

[6] Rohlf, F.J. Morphometric spaces, shape components and the effects of linear transformations. In LF Marcus, M.Corti, A.Loy, G.Naylor, DE Slice (eds). Advances in morphometrics. NATO ASI series. A life sciences Vol.284. New York: plenum, 1996, 117129.

[7] Humphries, J. Bookstein, F.L. Chernoff, B. Smith, G. Elder, R. and Poss, S. Multivariate discrimination by shape in relation to size. Syst. Zool. 30, 1981, 291-308.

[8] Bookstein, F., Chernoff, B., Elder, R., Humphries, J., Smith, G., and Strauss, R. Morphometrics in evolutionary biology (Special Publication 15: Philadelphia: The Academy of Natural Sciences of Philadelphia, 1985).

[9] Talwar, P.K. and A.G. Jhingran. Inland fishes of India and adjacent countries Vol 1. (A.A. Balkema, Rotterdam, 1991)

[10] Froese, R. and D. Pauly. Editors. FishBase. www.fishbase.org, 2010.

[11] S. Choudhury, P. Saikia, N. Sougrakpam, D. Brahma and K.Dutta. Assessment of morphometric variation and establishing taxonomic relationship among six species under Puntius genus. The Ecoscan: Special issue, 1(1), 2011, 233-237.

[12] Neil McAleece, P.J.D. Lambshead and G.L.J. Paterson. Originators . Biodiversity Pro. The Natural History Museum, London (Provider). 1997, URL: http://www.sams.ac.uk/

[13] Hurlbut, T. and Clay, D. Morphometric and meristic differences between Shallow and deepwater populations of White hake (Urophycis tenuis) in the southern Gulf of St Lawrence. Can. J. Fish. Aquat. Sci., 55, 1998, 2274-2282.

[14] Pollar, M., Jaroensutasinee, M. and Jaroensutasinee, K. Morphometric analysis of Tor tambroides by stepwise discriminant and neural network analysis. World Academy of Science, Engineering and Technology, 33, 2007, 16-20.

[15] Manimegalai, M. Karthikeyeni, S. Vasanth, S. Arul Ganesh, S. Siva Vijayakumar, T. and Subramanian, P. Morphometric Analysis - A Tool to Identify the Different Variants in a Fish Species E. Maculatus. International Journal of Environmental Sciences, 1(4), 2010, 481-497.

[16] S. Choudhury, P. Saikia, N. Sougrakpam, D. Brahma and K.Dutta. Assessment of morphometric variation and establishing taxonomic relationship among six species under Puntius genus. The Ecoscan: Special issue, 1(1), 2011, 233-237. 